\title{
Pengaruh Iklim Organisasi dan Tipe Kepribadian Terhadap Stres Kerja Pegawai Negeri Sipil Di Kantor Badan Kesatuan Bangsa dan Politik Di Provinsi Sumatera Utara
}

\section{Effect of Organizational Climate and Personality Types Against the Job Stress of Civil Servants at the Office of the National Unity Agency Politics in North Sumatra Province}

\author{
Anggi Tri Lestari Purba \\ Fakultas Psikologi, Universitas Medan Area, Indonesia
}

Diterima : 19 Juli 2020; Disetujui : 29 Juli 2020; Dipublish : 29 Agustus 2020

*Corresponding author: E-mail: anggitrilp@gmail.com

\begin{abstract}
Abstrak
Stres merupakan hal yang berbeda untuk orang yang berbeda. Banyak orang menggambarkannya sebagai perasaan tegang, cemas, atau khawatir. Secara ilmiah, perasaan-perasaan ini adalah semua manifestasi dari pengalaman stres, respons terprogram yang kompleks terhadap ancaman yang dirasakan yang dapat memiliki hasil positif dan negatif. Adanya banyak faktor yang menyebabkan timbulnya stres kerja pada karyawan. Penelitian ini bertujuan untuk mengetahui pengaruh iklim organisasi dan tipe kepribadian terhadap stres kerja pegawai negeri sipil di kantor badan Kesatuan Bangsa dan Politik di provinsi Sumatera Utara. Hipotesis yang diajukan adalah adanya pengaruh antara iklim organisasi dan tipe kepribadian terhadap stres kerja pada pegawai negeri sipil Kesabangpol di provinsis Sumatera Utara. Populasi dalam penelitian ini berjumlah 73 orang. Teknik pengambilan sampel adalah total sampling. Metode pengumpulan data adalah skala iklim organisasi, tipe kepribadian, dan stres kerja. Analisa data menggunakan analisis kovarian. Subjek pada penelitian ini memiliki tipe kepribadian yang berbeda dimana tipe A lebih tinggi dibandingkan tipe B dan stres kerja yang tergolong cendrung tinggi.
\end{abstract}

Kata Kunci: Iklim Organisasi; Stres Kerja; Kepribadian

\begin{abstract}
Stress is a different matter for different people. Many people describe it as feeling tense, anxious, or worried. Scientifically, these feelings are all manifestations of stressful experiences, complex programmed responses to perceived threats that can have positive and negative results. Many factors cause job stress on employees. This study aims to determine the effect of organizational climate and personality types on job stress at civil servants in the offices of the National Unity and Politics agency in the province of North Sumatra. The hypothesis proposed is the influence between organizational climate and personality type on job stress at civil servants in the office of the National Unity and Political Agency in the province of North Sumatra. The population in this study amounted to 73 people. The sampling technique is a total sampling. Data collection methods are the scale of the organization's climate, personality type, and job stress. Data analysis used an analysis of covariance. Subjects in this study have different personality types where type A is higher than type $B$ and job stress is classified as high.

Keywords: Organizational Climate; Job Stress; Personality
\end{abstract}

Rekomendasi mensitasi :

Purba, A.T.L. (2020). Pengaruh Iklim Organisasi dan Tipe Kepribadian Terhadap Stres Kerja. Jurnal Penelitian Pendidikan, Psikologi dan Kesehatan (J-P3K), 1 (2): 100108. 


\section{PENDAHULUAN}

Indonesia

adalah

negara

berkembang dengan jumlah penduduk yang diperkirakan sebesar 261.890.872 juta jiwa (Ilo.org). Salah satu pekerjaan yang diminati di Indonesia adalah menjadi PNS, hal ini terbukti pada tahun 2017 banyaknya masyarakat mengikuti penerimaan pegawai negeri sipil. Pegawai Negeri Sipil sebagai unsur utama sumber daya manusia aparatur negara yang mempunyai peranan akan menentukan keberhasilan penyelenggaraan pemerintahan dan pembangunan.

Pegawai negeri sipil merupakan satu diantara sekian banyaknya yang selalu di tuntut dan disorotin masyarakat untuk menghasilkan kerja sebaik mungkin. Salah satu bagian Pegawai negeri sipil di Indonesia adalah Kesbangpol, untuk menghasilkan hasil kerja yang baik, di butuhkan karyawan yang sehat fisik dan mental yaitu terhindar dari stres.

Stres disebabkan oleh rangsangan, dan rangsangan tersebut dapat berupa fisik atau psikologis, dan bahwa individu merespon terhadap rangsangan tersebut dengan sejumlah cara stres (Moorhead dan Griffin, 2013). Stres yang tidak diatasi dengan baik biasanya berakibat pada ketidakmampuan seseorang berinteraksi secara positif dengan lingkungannya, baik dalam arti lingkungan pekerjaan maupun di luarnya.

Saat ini, stres kerja merupakan ancaman yang sering dihadapi oleh berbagai macam organisasi dan merugikan individu tersebut serta organsiasi yang terkait. Menurut fenomena dalam penelitian ini, bahwa jam pulang kerja terlalu malam dan kadang melakukan tugas keluar kota dengan waktu yang tidak direncanakan dari jauh hari serta akan lembur lebih malam lagi di waktu tertentu.

Narasumber juga mengatakan bahwa tugas kerja yang banyak, kadang rekan kerja yang tidak saling bantu serta sumber daya manusia yang kurang memadai. Keadaan diatas menjadi stressor bagi pegawai sehingga mengalami stres kerja.

Oleh karena itu berdasarkan latar belakang permasalahan tersebut di atas maka peneliti tertarik untuk melakukan penelitian tentang pengaruh iklim organisasi dan tipe kepribadian terhadap stres kerja pegawai negeri sipil di kantor badan kesatuan bangsa dan politik provinsi Sumatera Utara.

Berdasarkan fenomena yang ada, maka rumusan masalah penelitian ini sebagai berikut: (1) Apakah ada pengaruh iklim organisasi terhadap stres kerja pegawai negeri sipil di kantor Badan Kesbangpol yang bertugas di Provinsi Sumatera Utara?, (2) Apakah ada pengaruh tipe kepribadian (tipe A dan tipe B) terhadap stres kerja pegawai negeri sipil di kantor Badan Kesbangpol yang bertugas di Provinsi Sumatera Utara?, (3) Apakah ada pengaruh iklim organisasi dan tipe kepribadian terhadap stres kerja pegawai negeri sipil di kantor Badan Kesbangpol yang bertugas di Provinsi Sumatera Utara?.

Tujuan dalam penelitian ini adalah untuk mengetahui: (1) Untuk melihat pengaruh iklim organisasi terhadap stres kerja pegawai negeri sipil di kantor Badan Kesbangpol Provinsi Sumatera Utara. (2) Untuk melihat pengaruh tipe kepribadian (tipe A dan tipe B) terhadap stres kerja 
pegawai negeri sipil di kantor Badan Kesbangpol Provinsi Sumatera Utara. (3) Untuk melihat pengaruh iklim organisasi dan tipe kepribadian terhadap stres kerja pegawai negeri sipil di kantor Badan Kesbangpol Provinsi Sumatera Utara.

Manfaat penelitian ini adalah sebagai berikut: (1) Manfaat Teoritis diharapkan dapat memberikan konstribusi serta memperkaya wacana ilmu psikologi terutama yang berhubungan dengan psikologi industri dan organisasi. (2) Dari segi praktis: (a) Hasil penelitian ini diharapkan dapat menjadi tambahan informasi bagi pegawai negeri sipil di Kesbang, sebagai bahan referensi dalam upaya meminimalkan stres kerja. (b) Bagi dunia penelitian psikologi, meemberikan informasi empirik tentang pengaruh iklim organisasi dan tipe kepribadian terhadap stres kerja, sehingga dapat digunakan sebagai penunjang untuk penelitianpenelitian selanjutnya.

Menurut Robbins (2006) stres merupakan kondisi dinamik yang di dalamnya individu menghadapi peluang, kendala, atau tuntutan yang terkait dengan apa yang sangat diinginkannya dan yang hasilnya dipersepsikan sebagai tidak pasti tetapi penting. Sedangkan stres kerja menurut Beer dan Newman merupakan situasi yang timbul dari interaksi manusia dengan pekerjaan yang diakibatkan oleh perubahan manusia yang menyimpang dari fungsi normalnya (dalam Luthans, 2011).

Oleh karena itu, dapat didefenisikan stres sebagai respon adaptif seseorang terhadap rangsangan yang menempatkan tuntunan psikologis atau fisik secara berlebihan kepadanya. Stres yang tidak dapat diatasi dengan baik biasanya berakibat pada ketidakmampuan seseorang beriteraksi dengan lingkungannya.

Robbins dan Judge (2013) mengemukakan aspek-aspek stres yang dapat digolongkan menjadi tiga aspek, yaitu: (a) Gejala Fisiologis. Gejala fisiologis merupakan gejala awal yang bisa diamati, terutama pada penelitian medis dan ilmu kesehatan. Stres cenderung berakibat pada perubahan metabolisme tubuh, meningkatnya detak jantung dan pernafasan, peningkatan tekanan darah, timbulnya sakit kepala, serta yang lebih berat lagi terjadinya serangan jantung. (b) Gejala Psikologis. Dari segi psikologis, stres dapat menyebabkan ketidakpuasan. Hal itu merupakan efek psikologis yang paling sederhana dan paling jelas. Namun bisa saja muncul keadaan psikologis lainnya, misalnya ketegangan, kecemasan, mudah marah, kebosanan dan suka menunda-nunda pekerjaan. Bukti menunjukkan bahwa ketika orang ditempatkan dalam pekerjaan dengan tuntutan yang banyak dan saling bertentangan atau dimana ada ketidakjelasan tugas, wewenang, dan tanggung jawab pemegang jabatan, maka stres maupun ketidakpuasan akan meningkat. (C). Gejala Perilaku. Gejala stres yang berkaitan dengan perilaku meliputi perubahan dalam tingkat produktivitas, absensi, kemangkiran, dan tingkat keluarnya karyawan, juga perubahan dalam kebiasaan makan, merokok dan konsumsi alkohol, bicara cepat, gelisah, dan gangguan tidur.

Salah satu penyebab terjadinya peningkatan stres adalah iklim organisasi 
itu sendiri. Hal tersebut terlihat dari faktor penyebab stres (Moorhead dan Griffin, 2013), salah satunya adalah tuntunan interpersonal terdiri atas: tekanan kelompok, pimpinan dan konflik antarpersonal. Hal tersebut merupakan bagian dari iklim organisasi, dimana iklim organsiasi berpengaruh pada proses menciptakan hubungan antarpersonal yang baik.

Pertama kali istilah iklim organisasi (organizational climate) diperkenalkan oleh Kurt Lewin pada tahun 1930-an. Kemudian istilah iklim organisasi dipakai oleh Tagiuri dan Litwin pada tahun 1968 yang mengemukakan sejumlah istilah untuk melukiskan perilaku dalam hubungan dengan latar atau tempat dimana perilaku muncul: lingkungan, lingkungan pergaulan, budaya, suasana, situasi, pola lapangan, pola perilaku, dan kondisi (dalam Shovia, 2010).

Menurut Davis \& Newstrom (2004), iklim organisasi adalah lingkungan manusia, tempat para pegawai organisasi melakukan pekerjaan. Iklim organisasi merupakan persepsi karyawan terhadap lingkungan perusahaan yang mempengaruhi karyawan dalam menjalankan tugas dan tanggung jawabnya, baik yang sifatnya fisik maupun psikologis.

Sedangkan menurut Litwin dan Stringer (Wirawan, 2007) bahwa iklim organisasi merupakan kualitas lingkungan internal organisasi yang secara relatif terus berlangsung, dialami oleh anggota organisasi, mempengaruhi perilaku mereka dan dapat dilukiskan dalam pengertian satu set karakteristik atau sifat organisasi. Iklim organisasi positif penting diciptakan di suatu instansi karena akan berdampak pada pada persepsi seseorang tentang apa yang diberikan oleh organisasi dan dijadikan dasar bagi penetuan tingkah laku anggota selanjutnya.

Menciptakan iklim organisasi yang baik bagi instansi membuat individu di dalam instansi tersebut terpacu untuk berprestasi dalam rangka mencapai tujuan organisasi. Di dalam menciptakan iklim organisasi yang baik tidaklah mudah, karena pada dasarnya setiap individu memiliki karakteristik (kepribadian) yang berbeda-beda.

Perubahan, persaingan berbagai tuntutan serta perbedaan karakteristik (kepribadian) tersebut membawa dampak terhadap tuntutan yang lebih tinggi pada setiap individu untuk dapat lebih meningkatkan kualitas kerja mereka, hal ini dapat menimbulkan dampak salah satunya yaitu stres kerja.

Menurut Stringer

menyebutkan bahwa ada enam aspek Iklim organisasi, yaitu: (a) Struktur yaitu merefleksikan perasaan bahwa karyawan diorganisasi dengan baik dan mempunyai definisi yang jelas mengenai peran dan tanggung jawab mereka. (b) Standarstandar yaitu mengukur perasaan tekanan untuk memperbaiki kinerja dan derajat kebanggaan yang dimiliki anggota organisasi dalam melakukan pekerjaannya dengan baik. Standarstandar yang tinggi artinya anggota organisasi selalu berupaya mencari jalan untuk meningkatkan kinerja. (c) Tanggung jawab yaitu aspek ini menggambarkan rasa tanggung jawab yang tumbuh dalam organisasi, sehingga setiap anggota benar- 
benar memiliki tanggung jawab yang besar terhadap pelaksanaan tugas, hasil dari pekerjaan dan mutu output. (d) Penghargaan atau imbalan yaitu mengindikasikan bahwa anggota organisasi merasa dihargai jika mereka dapat menyelesaikan tugas dengan baik. Meliputi imbalan atau upah yang terima karyawan setelah menyelesaikan pekerjaan. (e) Dukungan yaitu aspek ini akan mengungkap mengenai bagaimana suasana interaksi antar anggota organisasi. (f) Komitmen yaitu merefleksikan perasaan kebanggaan dan komitmen sebagai anggota organisasi. Meliputi pemahaman karyawan mengenai tujuan yang ingin dicapai oleh perusahaan.

Kepribadian adalah serangakain atribut psikologis yang relatif stabil yang membedakan satu dengan orang lainnya (Moorhead dan Griffin, 2013). Menurut Luthans (2011) Kepribadian adalah bagaimana orang mempengaruhi orang lain dan bagaimana mereka memahami dan melihat diri mereka, serta pola mereka dalam dan luar sifat-sifat terukur dan interaksi orang-situasi.

Kepribadian adalah pola cara yang relatif abadi yang seseorang merasa, berpikir, dan berperilaku. kepribadian mengacu pada set karakter yang relatif stabil, temperamen, dan kecenderungan yang membentuk persamaan dan perbedaan dalam perilaku orang. Jumlah aspek kepribadian yang bisa berfungsi sebagai moderator stres cukup besar.

Kepribadian harus dimiliki dalam setiap orang yang masuk ke dalam suatu organisasi, karena maju atau mundurnya suatu organisasi berada pada individunya masing-masing serta sistem yang telah dijalankan. McShane dan Glinow (2010) mengatakan kepribadian merupakan pola pemikiran, emosi, dan perilaku yang relatif abadi yang menjadi ciri seseorang, bersama dengan proses psikologis di balik karakteristik tersebut.

Pada dasarnya, kumpulan karakteristik yang membuat kita mirip atau berbeda dari orang lain. Orang memvariasikan perilaku mereka untuk menyesuaikan situasi, bahkan jika perilaku itu bertentangan dengan kepribadian. Orang-orang biasanya menunjukkan berbagai perilaku, namun dalam variasi itu ada pola yang dapat dilihat yang kita sebut sebagai ciri kepribadian.

Menurut Friedman dan Rosenman (dalam Moorhead dan Griffin, 2013) mengatakan pola perilaku dibagi menjadi 2 tipe, yaitu: tipe A yaitu individu yang ekstrem bersifat sangat kompetitif, sangat berdedikasi pada pekerjaan dan mempunyai rasa urgensi waktu yang kuat. Selain itu, orang ini memungkinkan bersifat agresif, tidak sabar dan sangat berorientasi kerja. Ia mempunyai dorongan dan motivasi besar dan ingin menyelesaikan sebanyak mungkin dalam waktu sesingkat mungkin.

Sedangkan tipe B yaitu individu yang ekstrem, sebaliknya kurang kompetitif, kurang berdedikasi pada pekerjaan, mempunyai urgensi waktu yang lebih lemah. Orang ini merasakan lebih sedikit konflik dengan orang atau waktu dan mempunyai pendekatan yang lebih seimbang dan rileks terhadap kehidupan. Ia mempunyai kepercayaan diri lebih besar dan mampu bekerja dengan irama yang konstan. 


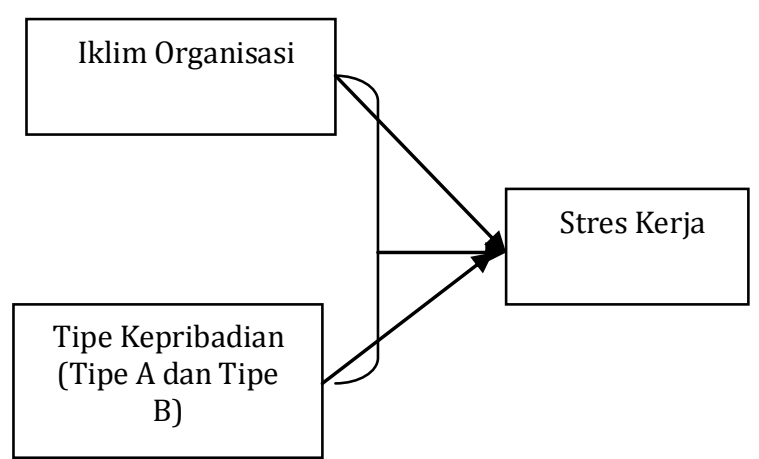

Hipotesis dalam penelitian ini terdiri dari tiga, yaitu: (1) Ada pengaruh iklim organisasi terhadap stres kerja pegawai negeri sipil di kantor Badan Kesbangpol di Provinsi Sumatera Utara. (2) Ada pengaruh tipe kepribadian (tipe A dan tipe B) terhadap stres kerja pegawai negeri sipil di kantor Badan Kesbangpol di Provinsi Sumatera Utara. (3) Ada pengaruh iklim organisasi dan tipe kepribadian terhadap stres kerja pegawai negeri sipil di kantor Badan Kesbangpol di Provinsi Sumatera Utara.

\section{METODE PENELITIAN}

Penelitian ini dilaksanakan pada pegawai negeri sipil Medan yang bertugas di badan kesatuan bangsa dan politik di Provinsi Sumatera Utara. Populasi dalam penelitian ini adalah anggota pegawai negeri Kesbangpol di Provinsi Sumatera Utara yang berjumlah 73 orang serta Sampel dalam penelitian ini adalah seluruh anggota pegawai. Teknik pengambilan sampel dalam penelitian ini menggunakan teknik total sampling.

Penelitian ini menggunakan teknik Analisis Kovarian (Anakova), yaitu penggabungkan antara regresi dan anova (Widiarsho, 2011). Regresi menguji seberapa jauh sebuah variabel independen mampu memprediksi besarnya variabel dependen dan anova menguji perbandingan rerata.

Jadi dengan menggunakan analisis kovarian, peranan variabel independen terhadap variabel dependen baik melalui prediksi maupun melalui perbedaan dapat diidentifikasi secara bersamaan (simultan).

\section{HASIL DAN PEMBAHASAN}

Hipotesis pertama pada penelitian ini, terdapat pengaruh yang signifikan antara iklim organisasi terhadap stres kerja. Berdasarkan hasil analisa statistik didapatkan, maka hipotesis pertama dalam penelitian ini terbukti secara signifikan bahwa ada pengaruh iklim organisasi terhadap stres kerja yang ditunjukkan oleh $\mathrm{F}=81.795$ dan $\mathrm{p}<0,05$ $(p=0,000)$, R Square sebesar 0.535.

Sedangkan hipotesis kedua pada penelitian ini, terdapat pengaruh signifikan antara tipe kepribadian terhadap stres kerja. Berdasarkan hasil analisa statistik didapatkan, maka hipotesis kedua dalam penelitian ini terbukti secara signifikan bahwa ada pengaruh tipe kepribadian terhadap stres kerja yang ditunjukkan oleh $\mathrm{F}=106.088$ dan $\mathrm{p}<0,05(\mathrm{p}=0,000)$, R Square sebesar 0.599 .

\begin{tabular}{llll}
\multicolumn{4}{l}{ Tabel 1. Deskriptif Tipe Kepribadian } \\
\hline Tipe & Jumlah & Mean & $\begin{array}{l}\text { Standar } \\
\text { Kepribadian }\end{array}$ \\
Subjek & & Deviasi \\
\hline Tipe A & 42 & 58,92 & 8,128 \\
Tipe B & 31 & 42,09 & 6,018 \\
Total & 73 & 51,35 & 11,467 \\
\hline
\end{tabular}

Berdasarkan penjelasan sebelumnya, telah diketahui bahwa iklim organisasi dan tipe kepribadian secara bersamasama memiliki sumbangan efektif terhadap stres kerja pada pegawai negeri 
sipil di kantor Kesbangpol Provinsi Sumatera Utara. Hal ini menunjukkan bahwa Artinya, semakin positif iklim organisasi yang dipersepsikan oleh pegawai mengakibatkan stres kerja yang alami karyawan akan semakin rendah.

Hal ini sesuai dengan penilitian Khairunnisah (2015) dan Abdilah, Anita, Anugerah (2016) yang menyatakan adanya pengaruh iklim organisasi terhadap stres kerja, yang berarti bahwa semakin baik dipersepsikan iklim organisasi maka akan menurunkan stres kerja pada pegawai. Sebaliknya, semakin buruk persepsi pegawai terhadap iklim organisasi, maka akan semakin tinggi tingkat stres kerjanya.

Maka dalam penelitian ini iklim organisasi yang baik atau tidak akan mempengaruhi kerja pegawai di pegawai negeri sipil di kantor Badan Kesbangpol Provinsi Sumatera Utara. Menurut Fincham dan Rhodes (Munandar, 2006) mengatakan stres dapat disimpulkan dari gejala-gejala dan tanda-tanda faal, perilaku, psikologikal dan somatik, adalah hasil dari tidak/kurang adanya kecocokan antara orang (dalam arti kepribadiannya, bakatnya dan kecakapanya) dan lingkungannya, yang mengakibatkan ketidakmampuan untuk menghadapi berbagai tuntutan terhadap dirinya secara efektif.

Munculnya stres dapat ditandai dengan terjadinya perubahan fisik dan psikologis dan di pengaruhi beberapa faktor salah satunya tuntutan antarpersonal (Moorhead \& Griffin, 2013). Hal tersebut merupakan bagian dari iklim organisasi, dimana iklim organisasi berpengaruh pada proses menciptakan hubungan antarpersonal yang baik.

Untuk menciptakan suasana kondusif dan nyaman dalam bekerja, pemimpin juga harus mampu mengelola dan menciptakan iklim organisasi yang positif. Nitisemito (dalam Rani, 2007), menjelaskan bahwa iklim organisasi adalah segala sesuatu yang ada disekitar para pekerja yang dapat mempengaruhi dirinya dalam menjalankan tugas-tugas yang dibebankan.

Pegawai yang memiliki pandangan yang positif terhadap iklim organisasi akan menilai pekerjaan tersebut secara positif juga. Persepsi positif ini akan memelihara semangat kerja Pegawai sehingga tidak merasakan adanya tuntutan kerja yang berlebih dan akan meningkatkan kinerja.

Selain iklim organisasi, dari hasil penelitian juga diketahui bahwa tipe kepribadian turut berpengaruh terhadap pada peningkatan stres kerja. Temuan ini sejalan dengan Moorhead \& Griffin, (2013) mengatakan perbedaan individual yang paling dikembangkan yang berhubungan secara pesifik dengan stres adalah perbedaan profil kepribadian tipe A dan B.

Individu tipe $\mathrm{A}$ bersifat sangat kompetitif, sangat berdedikasi pada pekerjaan dan mempunyai rasa uregensi waktu yang kuat. Selain itu, orang ini kemungkinan bersifat agresif, tidak sabar dan sangat berorientasi kerja. Ia mempunyai dorongan dan motivasi besar dan ingin menyelesaikan sebanyak mungkin dalam waktu sesingkat mungkin.

Sedangkan tipe B sebaliknya bersifat kurang kompetitif, kurang berdedikasi 
pada pekerjaan, dan mempunyai urgensi waktu yang lebih lemah. Orang ini merasakan lebih sedikit konflik dengan orang atau waktu dan mempunyai pendekatan yang lebih seimbang dan rileks dalam kehidupan. Ia mempunyai kepercayaan diri lebih besar dan mampu bekerja dengan irama yang konstan.

Berdasarkan penjelasan sebelumnya, telah diketahui bahwa iklim organisasi dan tipe kepribadian secara bersamasama memiliki sumbangan efektif sebesar $66.8 \%$ terhadap stres kerja pada pegawai negeri sipil di kantor Kesbangpol Provinsi Sumatera Utara. Hal ini menunjukkan bahwa masih terdapat $33.2 \%$ dari faktor lain yang mempengaruhi stres kerja dan faktor-faktor tersebut belum termasuk dalam penelitian ini, baik faktor lain yang bersumber dari internal, maupun yang bersumber dari eksternal.

\section{SIMPULAN}

Berdasarkan hasil-hasil yang telah diperoleh dalam penelitian ini, maka dapat disimpulkan bahwa terdapat pengaruh yang signifikan antara iklim organisasi terhadap stres kerja. Artinya semakin positif iklim organisasi dipersepsikan oleh pegawai, maka semakin rendah stres kerja yang di alami pegawai.

Terdapat pengaruh signifikan antara tipe kepribadian terhadap stres kerja, dimana tipe kepribadian A lebih besar pengaruhnya terhadap stres kerja dibandingkan tipe kepribadian B. Serta adanya pengaruh signifikan antara iklim organisasi dan tipe kepribadian terhadap stres kerja. dengan rata-rata subjek penelitian memiliki stres kerja pada kategori yang cendrung tinggi dan memiliki iklim organisasi pada kategori cendrung tinggi juga.

\section{DAFTAR PUSTAKA}

Abdillah, Anita \& Anugerah. 2016. Dampak Iklim Organisasi Terhadap Stres Kerja dan Kinerja Karyawan

Davis, Keith \& John Newstrom. 2004. Perilaku Dalam Organisasi. Edisi ketujuh. Jakarta: Erlangga. Jurnal Manajemen/Volume XX, No. 01. Universitas Riau.

Khairunnisah. 2015. Pengaruh Iklim Organisasi Terhadap Stres Kerja Pada Karyawan PT Pupuk Iskandar Muda Lhoksumawe. Fakultas Psikologi. Universitas Sumatera Utara

Luthans, Fred. 2011. Organizational Behavior: An Evidence-Based Approach. New York: McGraw-Hill.

McShane, Steven L and Von Glinow, Mary A. (2010). Organizational Behaviour Emerging Knowledge and Practice for The Real World. 5th $^{\text {th }}$ dition. New York: McGraw-Hill.

Moorhead, Gregory dan Ricky W. Griffin. 2013. Perilaku Organisasi: Manajemen Sumber Daya Manusia dan Organisasi. Edisi kesembilan. Jakarta: Salemba Empat.

Munandar, Ashar Sunyoto. 2006. Psikologi Industri dan Organisasi. Jakarta: Universitas Indonesia (UI-Press).

Rani, Deasy Amalia. 2007. Hubungan antara iklim Organsiasi dengan Peluang Untuk Berkreasi Pada Karyawan Desain PT. Batik Dahar Hadi. Program Studi Psikologi Fakultas Kedokteran. Universitas Diponegoro

Robbins, Stephen P. 2006. Perilaku Organisasi. Edisi kesepuluh. Jakarta: PT Indeks Kelompok Gramedia.

Robbins, Stephen P \& Judge, Timothy A. 2013. Organizational Behavior. 15th Edtion. New Jersey: Pearson Education.

Shovia R E. 2010. Faktor-Faktor yang Mempengaruhi Stres Kerja Karyawan Pearushaan Daerah Jasa Transportasi Transpakuan Bogor. Bogor: Institut Petanian Bogor.

Stringer, Robert. 2002. Leadership and Organizational Climate: The Cloud Chamber Effect. Upper Saddle River, NJ: Prentice Hall. 
p-ISSN : 2721-5393, e-ISSN : 2721-5385

www.jurnalp3k.com/index.php/J-P3K/index

Wirawan. 2007. Budaya dan Iklim Organisasi: Teori, Aplikasi dan Penelitian. Jakarta: Salemba Empat. 